\title{
㷜関節軟骨のラマン分光特性と圧縮負荷の関係
}

\author{
東藤正浩"1 ，但野 茂 ${ }^{* 1}$

\section{Raman Spectroscopic Characteristics of Knee Joint Cartilage under Compressive Loading}

\author{
Masahiro TODOH ${ }^{* 2}$ and Shigeru TADANO \\ $*^{2}$ Division of Human Mechanical Systems and Design, Faculty of Engineering, \\ Hokkaido University \\ Kita 13, Nishi 8, Kita-ku, Sapporo, 060-8628 Japan
}

\begin{abstract}
In this study, component analysis as mechanical evaluation was performed by Raman spectroscopy for cartilage consisted by macromolecule (such as collagen fiber and proteoglycan). Raman spectroscopy is a vibrational spectroscopy by Raman scattering, and allows simultaneous measurement of organic and inorganic components. The spectroscopy is suitable for measurement of biological samples because of little effect on water. The cartilage specimens ware cut out from rabbit knee joint and their Raman spectrum were analyzed. In addition, load response to cartilage by the spectroscopy. The result of Raman shift for hydroxyproline and pyranose shows mechanical response. Therefore, this study indicated the possibility of stress analysis for cartilage with Raman spectroscopy.
\end{abstract}

Key Words : Biomechanics, Raman spectroscopy, Knee joint, Cartilage, Compression

\section{1. 緒言}

大腿骨と脛骨, 膝蓋骨で構成される膝関節は, 人 体で最も大きな関節である. 屈伸運動機能だけでは なく，下肢に生じる衝撃エネルギーの多くは膝関節 によって吸収される ${ }^{(1)}$. 変形性関節症 (Osteoarthritis: OA）は労衝やスポーツ, 外傷などによる過剩な力学 的負荷が原因で発症する関節軟骨の退行性疾患であ り, 高齢者の日常活動性 (Activity of daily living: $\mathrm{ADL}$ ) および生活の質（Quality of life:QOL）を阻害 する最も多い原因の一つである. 高齢化が進む中で, この病態を十分に把握し, 適切な診断を行うことが 求められている(2).

本研究では, コラーゲン線維, エラスチン, プロテオ グリカンなど高分子から構成される膝関節軟骨の力学特 性評価法として, ラマン分光法による成分解析を行った. ラマン分光法は, 光と分子振動の相互効果を利用した解 析手法である. 水分の影響を受けにくいという特徽を持 ち，有機および無機両成分の成分解析が可能である.こ れらにより, ラマン分光法は生体材料の測定に適してい

${ }^{{ }^{* 1}}$ 正員, 北海道大学 (T060-8628 北海道札幌市北区北 13 条西 8丁目)

E-mail: todoh@eng.hokudai.ac.jp
る. 本研究では, ウサギ膝関節の脛骨顆より溙関節軟骨 試験片を採取し，顕微レーザーラマン分光装置によりラ マンスペクトル解析を行い，力学的負荷に対するラマン スペクトルの応答について調査した。

\section{2. 手法}

$2 \cdot 1$ 試験片 ウサキ滕関節から採取した脛骨顆部 を試験片として使用した.ダイヤモンド・ソー(Model650, South Bay Technology）を用い，脛骨矢状面䉼面を作製し た. 測定面はエメリー紙で研磨した後, 超音波洗浄機 (US-1, エスエヌディ社)を用いて洗浄した.

$2 \cdot 2$ ラマン分光則定 単一の振重数りを持つ励起レ 一ザーを, 固有の分子振重数 $v$ を持つ物質に照射すると, レイリー散乱のよるレーザーと同様の振動数 $v_{i}$ の散乱光, ストークス散乱による振動数 $\boldsymbol{v}_{i}$-v の散乱光，アンチスト 一クス散乱による振動数 $v_{i}+v$ の散乱光が観測される. 入 射光とストークス散乱光の振動数の差 $v$ をラマンシフト と呼び，物質特有の值を取るため，物質の特定やその特 性を知るためにラマン分光測定か浰用される( ${ }^{(3)}$.

本研究では, ラマン分光測定装置として北海道大学創 生科学研究棟オープンファシリティ0顕微ラマンマイク

日本機械学会[No.13-8]M\&M2013 材料カ学カンファレンス CD-ROM論文集[2013.10.12-14] 
ロスコープシステム (in Via Reflex, Renishaw) を使用した. 励起レーザーとして, NIR laser (HPNIR785, Renishaw: 波 長 $785 \mathrm{~nm}$ ）を使用した.

また, 力学的負荷状態でのラマンスペクトル測定では, 装置内に玨縮負荷冶具を設置し，ラマンスペクトル測定 を行った.

\section{3. 結 果}

ウサギ膝軟骨のラマンスペクトル測定結果を Fig. 1 に 示す．測定したスペクトル分布から，重心法を用いてピ ークシフトを算出した. 滕軟骨試験片 $(\mathrm{n}=5)$ へ圧縮負荷 を与え, Fig. 1 に示した各成分スペクトルのピークの負荷 応答を解析した. 無負荷状態と負荷状態でのラマンスペ クトルのピークの変化量を Fig. 2 に示寸. 各成分におけ るスペクトルのピーク位置の変化量 $(20 \mathrm{~N}-0 \mathrm{~N})$ を比較し たところ, Pyranose およびHydroxyproline においてスペク トルのピークの変化に有意性が見られた. Pyranose は軟 骨に含まれる多糖類に見られる成分であり， Hydroxyproline は軟骨を構成しているコラーグン線維の 主要な成分として，水素と結合することによりコラーゲ ン線維の安定性に寄与している.これらのことから，軟 骨に含まれる成分のうち，上記 2 種類の成分の力学的応 答をラマンスペクトルから推定できることか確認できた。 各成分におけるスペクトルの強度に関して無負荷状態 $(0 \mathrm{~N})$ と負荷状態 $(20 \mathrm{~N})$ に関して比をFig. 3 に示す. $\mathrm{n}=5$ とし, 各成分同士で比較した. スペクトル強度の変 化に関して，各成分において差はなく，負荷状態と無負 荷状態でのスペクトルの強度にも有意的な変化は見られ ないことが確認された。

\section{4. 考察}

ラマンスペクトル解析によって，膝関節軟骨に含まれ る成分の中で, Pyranose およびHydroxyproline でのラマン シフトが力学的負荷に対して応答性を示すことが確認で きた.この結果から，ラマン分光法により，軟骨組織内 のこれらの成分に関してラマンシフトと力学的負荷との 間の関係を定量化することが可能となれば，非侵襲での 軟骨力学特性評価が可能になると考えられる. 今後負荷 条件などの検討を行い，軟骨組織への力学的評価法とし ての有効性をさらに検討する予定である.

\section{文献}

(1) 越智光夫:最新整形外科学大系 17 膝関節-大腿 株 式会社, 中山書店, 2-30 (2006).

（2）古賀良成 : 変形性腠関節症, 南江堂, 2-4 (2008).

(3) 西岡利勝, 錦田晃一, 寺前紀夫 : 顕微赤外・顕微ラマ
ン分光法の基礎と応用. 技術情報協会, 12-15 (2008).

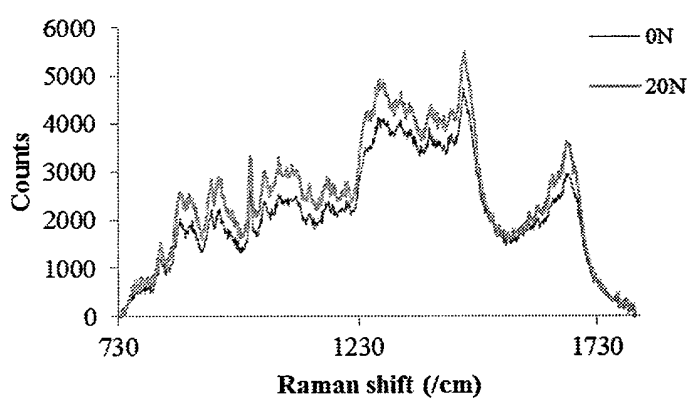

Fig. 1 Raman spectrum of rabbit knee cartilage $(0 \mathrm{~N}$ and $20 \mathrm{~N}$ ).

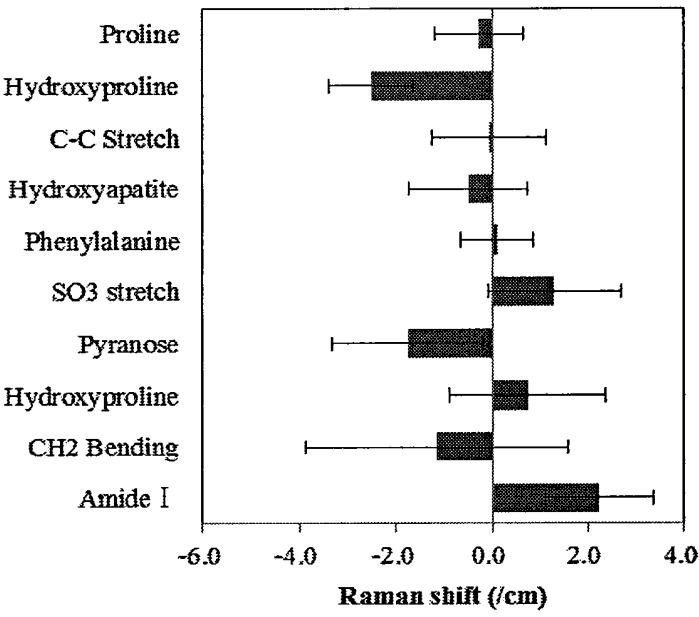

Fig. 2 Changes in Raman shift under different loading conditions.

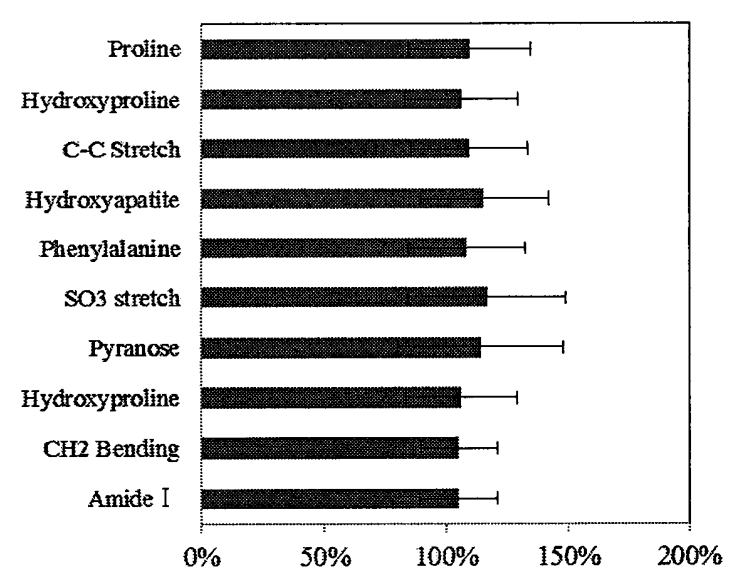

Fig. 3 Intensity ratio of the Raman spectra under different loading conditions. 